\title{
WestVirginiaUniversity
}

THE RESEARCH REPOSITORY @ WVU

Graduate Theses, Dissertations, and Problem Reports

1999

\section{Verbal aggression in sibling relationships}

Shannon Marie Brogan

West Virginia University

Follow this and additional works at: https://researchrepository.wvu.edu/etd

\section{Recommended Citation}

Brogan, Shannon Marie, "Verbal aggression in sibling relationships" (1999). Graduate Theses,

Dissertations, and Problem Reports. 705.

https://researchrepository.wvu.edu/etd/705

This Thesis is protected by copyright and/or related rights. It has been brought to you by the The Research Repository @ WVU with permission from the rights-holder(s). You are free to use this Thesis in any way that is permitted by the copyright and related rights legislation that applies to your use. For other uses you must obtain permission from the rights-holder(s) directly, unless additional rights are indicated by a Creative Commons license in the record and/ or on the work itself. This Thesis has been accepted for inclusion in WVU Graduate Theses, Dissertations, and Problem Reports collection by an authorized administrator of The Research Repository @ WVU. For more information, please contact researchrepository@mail.wvu.edu. 
Verbal Aggression in Sibling Relationships

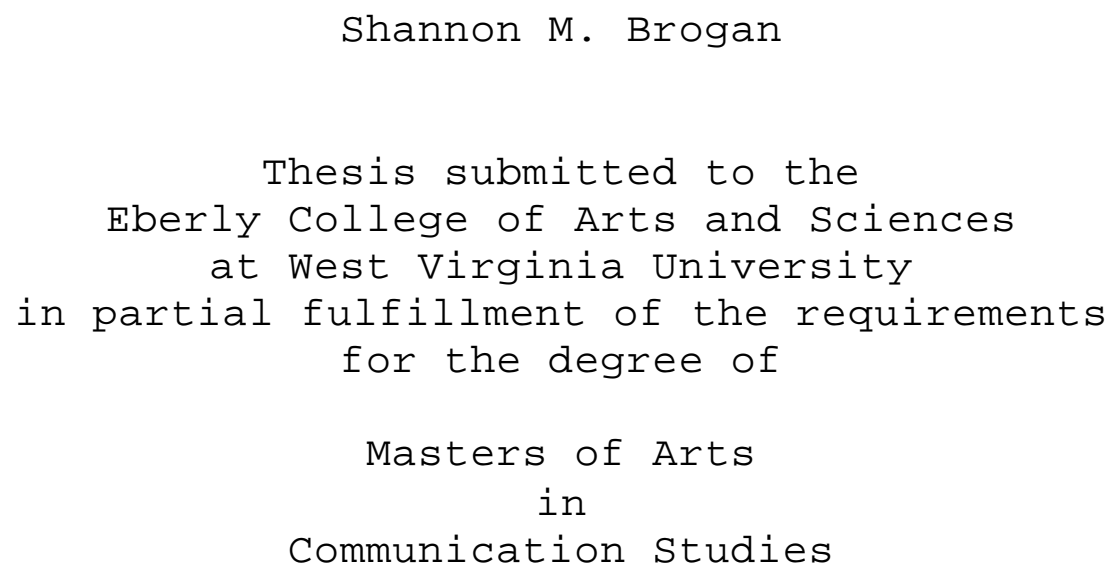

Robert A. Barraclough, Ed.D., Chair James C. McCroskey, Ed.D. Brian R. Patterson, Ph.D.

Morgantown, West Virginia 


\begin{abstract}
Verbal Aggression in Sibling Relationships

Shannon M. Brogan

The major focus of this study was to further

investigate the area of sibling verbal aggression. In order to research this area, students at West Virginia University and their siblings were asked to complete a questionnaire about verbal aggression. The results showed that self-reports of verbal aggression were consistent with other reports. Results also showed that male same sexed siblings were more likely to display more verbal aggression than all other combinations. Results revealed that males self-reports of verbal aggression were higher than females. Results also indicated that males are reported by their siblings to be more verbally aggressive than females. These results lead to the conclusion that the sibling relationship is important and that the communication aspect in this area is one that communication scholars should further research.
\end{abstract}




\section{ACKNOWLEDGEMENTS}

First, I would like to thank my thesis committee. Dr. Robert Barraclough, thanks for being there when I needed advice on my thesis, classes, or life. To Dr. Brian Patterson, thank you for helping me with my thesis and helping me figure out what I need to do with my life. To Dr. Jim McCroskey, thanks for helping me learn to write long papers and for being patient with me. You made my thesis less stressful and were always there for me with a word of encouragement especially when it came to Standardized Tests.

Next, I would like to thank all of my fellow Master's students who went through this ten months of "boot camp" with me. We have definitely had our share of laughs while keeping each other motivated not to rent U-hauls and drive as far away from Morgantown as possible. I remember walking in the first day and by the time we left the meeting we were all ready to pack our bags and never look back. However, the twelve of us have survived and have grown as a class. Every one of you has left a special place in my heart. I will never forget you guys and all that you have done for me. Sybil, what can I say, we are like Tweedle Dee and Tweedle Dum. Wherever one of us were 
you could also find the other. Thank you for helping me through the first few months. You helped me adjust and we pretty much became friends instantly. Chic-N-Bones is well off because of the both of us always eating and drinking there. Mike all I can say is "What the Dilly-o." I will never forget the blown up Mountain Dew bottles and the crosses on the side of the road. You Buffalo people must be a little socially deprived. Randy you are such a wonderful friend. You were there when I had problems and always gave me advice. I will never forget all of our study sessions. Sybil, Mike, and Randy we worked awesome together and I will truly miss all of you. Liz, we could write a book on relationships. However, we have both survived and became stronger women. Thanks for being such a great friend. Tomoko all I can say is you go girl. I have so much admiration for you. You came in to a program where English was your second language. You are such a wonderful role model for anyone who wants to travel abroad. Thank you for sharing your culture with me. You allowed us to "Americanize" you in so many ways and showed how openminded you truly are. Jamie, you always reminded me of the warm weather and the beaches. Dane, your uplifting personality always showed me that bad days would always get 
better. I appreciate your positive personality. Cheryl, you showed us the meaning of family. You went through this program and your family was behind you every step of the way. You managed to balance school and family and to me that shows what a wonderful wife and mother you are. Chris, I admired your strength and faith. You showed me that a relationship with God is important and keeps you going when you are in need. John, I will always remember you as Sargent Cole. Good luck in Doc. School-I am sure you will be wonderful. Gabe, I enjoyed talking to you. You were so laid back and one of the nicest people I have met. Thank you all for sharing these past ten months with me. We have formed a bond that is very unique. I truly will miss every one of you. I love all of you and will never forget all of our struggles and good times.

Renee what can I say. You have been such a strength for me this year. You were there to keep my head up whenever I needed some advice on life. Thank you for helping me learn to not settle for anything less then what I deserve. Thanks for going through all of my guy problems and for being there when I needed a shoulder to cry on. You have really been like a second mom to me. However, I will never forget who you wanted me to live with-I will 
still get you back. I will really miss you. Michelle, thanks for helping me with always checking on me when I was sick or having a bad day. You are such a wonderful person. Bethany, thanks for typing my envelopes and always helping me. You all are the best secretaries in this world. You took me in and treated me like one of your own kids. I will never forget you and all the times we shared.

To all of the Doctorate students (Joe, Katherine, Kelly, Allen, Mary, and Kris). Thanks for helping me out with either schoolwork or TA responsibilities. A special thanks to Joe for helping me look for jobs and being there whenever I needed a friend to talk to. I will truly miss all of you.

A special thank you goes out to all of the professors in the Communication Studies Department at West Virginia University. Thanks for accepting me in to one of the best departments. You taught me a work ethic that I will value for the rest of my life. A special thank you to Ted Avtgis. Ted, thanks for believing in me enough and helping me get my first publication. You have showed me that I need to keep trying regardless of what has happened in the past.

Thanks mom, dad, Erin, Kelly, Joe, and Maddie. I love vi 
you all more than you will ever know. You have been there to help me grow and encouraged me to be the best person I could be. You always showed me that I could succeed if I put my mind to it. I love you all and am so glad that you encouraged me not to give up even when I felt like it. Thanks for being the best family in the world.

Thanks to my best friends. Samm, Georgia, and Bryn, you were always there to check on me and tell me how proud you were of me. I love you all and am glad that we have been able to stay friends for so many years. Thanks to the Nottke's and the Weigly's. I always knew that you all were pulling for me. You were always there when I came home to tell me how proud you were of me. I love you all like you were part of my own family. Robby, thanks for keeping me company on the weekends and for being like a little brother to me. I enjoyed watching you play basketball and taking care of you every time you got hurt.

Last but not least, I would like to thank my ohio University mentor Dr. Candice Thomas-Maddox. Thank you for encouraging me to go to Graduate school and for believing in me. When I think of what I would want to be as a teacher, you come to my mind. You showed me that you need to love what you do and be there for your students. Thank vii 
you for helping me develop my love for the classroom and people.

All I can say is thank you. You all have helped me through a year of many obstacles and growth. May you all be blessed in many ways. I will truly miss all of you. However, as I begin a new journey in my life I hope that you will all continue to be a part of my life for without every one of you I would not be the person I am today. 
This thesis is written in honor of my family.

Mom and Dad-you two have been my biggest fans. You were there when I needed encouragement and always told me how proud you were of me. You showed me that I am special and that family is very important. It is kind of ironic that I am doing my thesis on sibling rivalry. Thank you for keeping your faith and for allowing Kelly, Erin, and I to go through our teenage years. I love you both very much!

Kelly and Erin-who would ever of thought that we would end up friends. I love you both. You are not only my sisters, but two of my best friends. Thank you for growing up with me and for experiencing sibling rivalry at its greatest. We have grown up so much over the years and for that I love you.

Joe and Maddie-you are the latest editions to the Brogan family. Joe, I am glad that we overcame our differences and have been able to work towards a relationship. Maddie, we are the only two people that have Poo attached to the end of our names. We will always be Auntie Poo and Maddie Poo. Thank you for experiencing Graduate school with me.

You are the best family anyone could ask for. Thank you for the love and support you have shown me throughout the year. Without you I would have not developed in to the person I am today. 


\section{In Memory of Charlotte Frame Martin \\ January 2, 1931 - June 19, 1999}

Thank you for showing me the value of family and life. You were a great woman that taught me to fight for what you wanted and never give up on myself even when others may not believe in me. Your strength and love for your family is what I hope to carry on in my own life. You were truly loved and will be missed by many. 


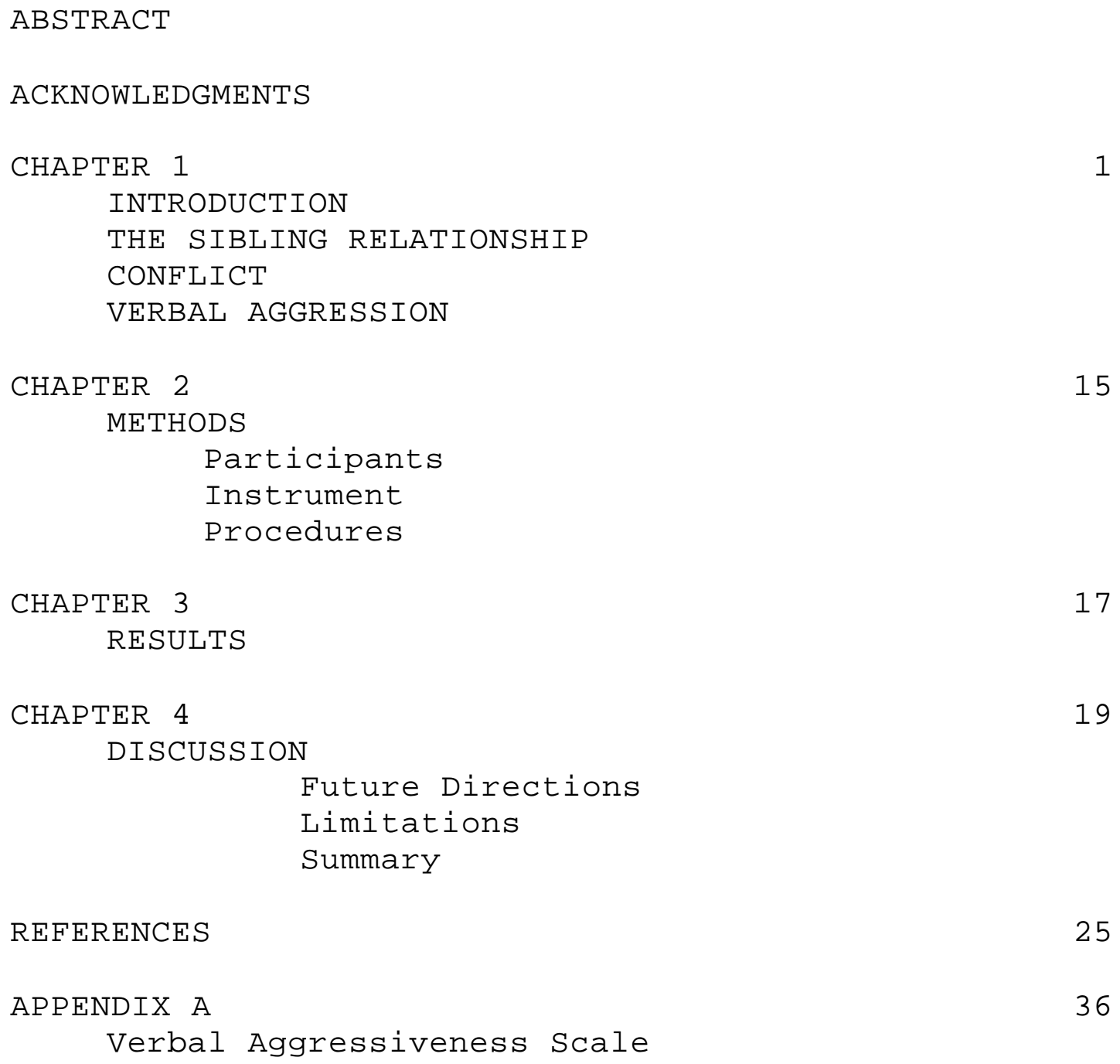

INTRODUCTION

THE SIBLING RELATIONSHIP

CONFLICT

VERBAL AGGRESSION

CHAPTER 2

METHODS

Participants

Instrument

Procedures

CHAPTER 3

17

RESULTS

CHAPTER 4

19

DISCUSSION

Future Directions

Limitations

Summary

REFERENCES

25

APPENDIX A

Verbal Aggressiveness Scale 
Chapter 1

INTRODUCTION

The following manuscript is a Master's thesis submitted in partial fulfillment for a Communication Studies Master's degree. The major focus of this document is on sibling verbal aggression. First, a review of relevant sibling literature is given with a rationale for this study. Next, conflict and verbal aggression are examined. The methods used in this study are given as will as the results of the study are reported. A discussion of the study and its results as well as future directions and limitations are given. Following the discussion are a list of references used for this thesis as well as appendices. The abstract gives an overview of the entire study including a statement about the investigation, the methods used to conduct the study, and the outcomes and conclusions of the study. 
Verbal Aggression in Sibling Relationships

The sibling relationship often lasts throughout most people's lives. According to Goode (1994), eighty percent of Americans have a sibling relationship. A considerable amount of research has been gathered on parent-child communication (see for example: Beatty, Burant, Dobos, \& Rudd, 1996; Beatty \& Dobos, 1992; Beatty, Zelley, Dobos, \& Rudd, 1994; Martin \& Anderson, 1995; Stafford \& Bayer, 1993); however, siblings also have a relationship worthy of investigating

Communication scholars have identified fathers' trait verbal aggressiveness (Beatty et al. 1996; Beatty et al. 1994) and communication motives (Martin \& Anderson, 1995) as important influences on the father-adult child communicative relationship. However, the relationship between trait verbal aggressiveness and communication motives has not yet been established. This study addresses several questions concerning the similarities and differences in trait verbal aggressiveness and the communication motives for older and younger male/female siblings.

The definition of a sibling relationship has varied from biological to the social-psychological perspective. 
Cicirelli and Nussbaum (1989) define sibling relationships as :

The total of interactions (actions, verbal, and nonverbal communication) of two or more individuals who share common biological parents, as well as their knowledge, perceptions, attitudes, beliefs, and feelings regarding each other, from the time when one sibling first became aware of the other (p. 283-284). This definition assumes that both parties are exchanging information and mutual influence. Siblings are thought by some to influence each other earlier than the Cicirelli and Nussbaum (1989) conceptualization of sibling relationships states. Some researchers argue that the sibling relationship is often influenced before the second child is born (Parke, 1992). The relationship with the older child is being altered as parents adjust to the coming of their second child (Dunn \& Kendrick, 1982). Noller and Fitzpatrick (1993) called the sibling relationship the "forgotten relationship" in communication research. And although it often contains a great deal of conflict, it is a relationship that is maintained over time by the participants. As such, it is basically a life-long relationship (Cicirelli, 1995; Fitzpatrick \& Badzinski, 1994; Noller \& Fitzpatrick, 1993; Vangelisti, 1994). 
Siblings take on various roles as brothers and sisters. For instance, they take on the roles of a friend, competitor, manager, and teacher (Buhrmester, 1992).

People also look to their siblings to provide companionship, comfort, affect, and friendship (Goetting, 1986). Goetting stated that siblings often support and protect one another from their parents when parents are verbally and/or physically abusive towards their children. The more emotional closeness between siblings, the greater the contact and commitment in the sibling relationship (Lee, Mancini, \& Maxwell, 1990).

Throughout siblings' lives, they can form several types of bonds with one another. Bank and Kahn (1955) stated "there is no simple, time-honored, socially approved, all-pervasive sibling relationship; rather, there are a multiplicity of bonds that arrange themselves into a finite number of predictable patterns" (p. 15). A sibling bond can consist of three things: a tie that unites, an obligation or an agreement, and a connection or a system of connections (Bank \& Kahn, 1955).

Over half of the conflict in families involves siblings (Montemayor \& Hanson, 1985). Jealousy and rivalry among siblings can be traced through mythology, literature, history, and religion (Dunn, 1988a). Siblings often deal 
with conflict by screaming at one another (Goodwin \& Roscoe, 1996). Stormshak, Bellanti, and Bierman (1996) found that most verbal aggression between siblings takes place outside of the sight of parents. Therefore, parents tend to underestimate the amount of conflict between their children. Parents also appear unable to stop or prevent destructive communication from taking place (Stormshak, et al., 1996). Dunn (1988a) noted that parents often feel responsible for the communication of hostility or aggression between children. The more quarreling and destructive communication in the sibling relationship, the less companionship, intimacy, affection, and interaction between siblings (Buhrmester, 1992; Montemayor \& Hanson, $1985)$.

Rival comes from the Latin word Rivalis which means having rights. Siblings have the tendency to rival against one another. For example, one child can rival another for the love of a parent, for a prized family role and so on. However, many forms of sibling aggression are not rivalrous. This has to do with a forbidden satisfaction or the fulfillment of a deeper emotional need. For instance, some sibling aggression and rivalry is an attempt to humiliate; or one may live a part or all of one's life 
knowing that the presence of a brother or a sister makes one physically or emotionally unsafe.

Frequently, the birth of a second child has been portrayed as traumatic to a first-born child. Gudykunst, Yoon, and Nishida (1986) found that when only two children are present there is an intensive rivalry between siblings. Research indicates that "most first-born children showed signs of disturbance following the sibling's birth" (Dunn, 1988b, p. 170). The first-born child usually experiences emotions of displacement. Dunn and Stocker (1989) speculated that the sibling-sibling relationship is mediated by the first-born child's emotional well being. Insecure first-borns have a more difficult time accepting and incorporating the new child into the family system.

\section{Conflict}

There is a significant amount of conflict for most children and adolescents (Bank \& Kahn, 1982; Buhrmester \& Furman, 1990; Dunn, 1985; Furman \& Buhrmester, 1992; Lamb \& Sutton-Smith, 1982; Montemayor \& Hanson, 1985). Siblings provide companionship like friends; however, unlike friends, siblings usually differ in age, are bound by involuntary ties, and may or may not like each other as individuals. When focusing on research, sibling conflict 
is typically discussed as the outward manifestation of unconscious processes of rivalry (e.g., Faber \& Mazlish, 1987; Freud, 1955; for an important exception, see Dunn, $1988)$.

The structure of conflict episodes has been described by a number of theorists and researchers (e.g., Berscheid, 1986; Hay, 1984; Shantz, 1987; Shantz \& Hobart, 1989). A conflict event can be analyzed in the following three stages: what is happening when conflict erupts ("onset"), what happens during the episode ("process"), and what happens afterwards ("aftermath").

Among siblings, two studies revealed that verbal exchanges and property disputes were common precipitants. Quarrels over duties, chores, privileges or special treatment by parents were less frequent (Goodwin \& Roscoe, 1990; Roscoe et al., 1987). Montemayor and Hanson (1985) found that most sibling quarrels were due to "interpersonal concerns" (teasing, extending courtesies, turn taking). It appears that friends quarrel over relationship concerns and issues arising from shared interactions; whereas, siblings enter into conflict over issues of shared life and personality differences. After reviewing this literature, it is believed that it is important to identify the influence of verbal aggression in the sibling relationship. 


\section{Verbal Aggression}

Verbal aggression is defined as a predisposition to attack another's self-concept rather than, or in addition to, their positions on issues (Infante \& Wigley, 1986). Cahn (1996) stated that verbally aggressive messages are a prevalent type of family violence. These are messages sent with the intent of hurting receivers (Infante, 1995;

Infante \& Rancer, 1996). Verbal aggression may cause people to feel embarrassed, inadequate, humiliated, hopeless, desperate, or depressed (Infante, 1987). Communicating aggressively in families can be viewed as ineffective and inappropriate (Beatty, Burant, Dobos, \& Rudd, 1996). Additionally, verbal aggression between siblings can lead to social difficulties with peers (Stormshak et al., 1996). Researchers have also found that people use more verbal aggression when involved in a family dispute than when involved in organizational disagreements (Infante, Myers, \& Buerkel, 1994).

The subject may report being verbally aggressive, but they may argue that the sibling was verbally aggressive first. Hence, siblings may be similar in verbal aggression due to their genetics or environment (Beatty \& McCroskey, 1997; Infante, 1995; Martin \& Anderson, 1995a). There are questions about whether self-report or other report would 
be more appropriate. Some people have questioned the issue of self-report because of the self-serving nature of selfreport data.

Accordingly, this study is designed to test the

following:

RQ1: Are self-reports of verbal aggression consistent with sibling reports?

Kinney (1994) stated that verbally aggressive messages produce various negative emotional responses, including anger, annoyance, and sadness. People who report being verbally aggressive with their siblings would be expected to be less satisfied with the relationship. People would also be expected to have less trust in their siblings when they perceive their siblings as being verbally aggressive. Trust reflects caring and being responsive to each other's needs (Holmes \& Rempel, 1989). Trust in a relationship is also positively related to the quality of communication in the relationship (Collins \& Repinski, 1994).

Beatty and his colleagues researched verbal aggression within the father-son relationship. They investigated the impact of verbal aggression on the adult sons' perceptions of their fathers use of sarcasm and criticism (Beatty et al., 1996; Beatty et al, 1994). Verbal aggression was 
found to be a predictor of sons' perceptions of fathers' sarcasm and criticism behavior.

Verbal aggression was found to occur more inside the family than outside the family. A father's verbal aggressiveness also helps understand the father-son communication relationship. The older brother may be higher in verbal aggressiveness since the older male sibling often takes on the parent-like role instead of the younger male sibling (Dunn, 1993).

In the sibling relationship, it is possible that the sex of the siblings could influence the communication between the dyads. The sex of the individuals in the sibling dyad is related to the type of communication in the relationship (Floyd, 1995, 1996, 1997). For example, Buhrmester (1992) found that women have a higher need to self-disclose to their sisters than to their brothers. The sex of the sibling is also related to the amount of conflict. Montemayor and Hanson (1985) found more conflict between same-sex siblings than opposite-sex siblings. For verbal aggression, research has consistently shown that men are more verbally aggressive than women, and that both men and women expect men to be more verbally aggressive (Martin \& Anderson, 1996a; Nicotera \& Rancer, 1994). Sibling dyads where both individuals are female may be less verbally 
aggressive than male and mixed sex dyads. However, it is possible that women are more verbally aggressive than men in some relationships.

Accordingly, this study is designed to test the following:

H1: Same sex sibling pairs will display more verbal aggression than mixed sex sibling pairs.

Infante, Bruning, and Martin (1994) found that people believe using verbally aggressive messages is justified when teasing someone. Infante (1995) argues that teasing is verbally aggressive. Others claim that teasing can be constructive, not destructive, to a relationship. One study found that teasing messages were rated as causing "little hurt" (Martin, Anderson, \& Horvath, 1996). Goodwin and Roscoe (1996) also identified teasing as a common form of destructive communication between siblings, noting that women reported being teased more than men. Teasing can "threaten face needs, create negative identities, and embarrass recipients" (Alberts, Kellar-Guenther, \& Corman, $1996, \mathrm{p} .338)$

Richardson et al. (1986) gathered data from young adolescents from intact families with at least two children to explore the link between family structure, family functioning, and time spent with parents. Adolescents who 
were further in age from their siblings spent more time with their fathers than those who were closely spaced. Kidwell (1981) found that adolescents with a mean sibling spacing of less than five years indicated that fathers were more strict than those with wider spacing. When sibling spacing was wider, adolescents perceived their parents' disciplinary behavior as more fair. Sibling spacing did not influence perceptions of mother strictness, but males rated their mothers as more strict than did females.

Buhrmester (1992) provided evidence that older and younger siblings' perceptions of the level of conflict in their relationships differed, with increased divergence in adolescence. Older siblings viewed their younger siblings as an annoyance, while younger siblings reported greater intimacy and more admiration for their older siblings.

The relationship with an older sibling may have important consequences for the younger sibling. Studies have shown that older siblings often serve as guides or teachers for younger siblings (Dunn \& Kendrick, 1982; Klagsbrun, 1992; Vandell et al., 1987). Research also indicates that older siblings are more likely to influence younger siblings than to be influenced by them (e.g., Bryant, 1982; Newman, 1991; Rogers \& Rowe, 1988). The hierarchical quality (Dunn, 1983) of sibling relationships 
may be salient in terms of development since older siblings generally experience developmental tasks before younger siblings do.

Male and female sibling interactions can depend upon masculine and feminine gender socialization (Floyd, 1996). Buhrmester (1992) found a trend suggesting that adolescent girls reported greater intimacy with siblings than did boys. Findings from another study suggest that girls viewed their sibling relationships as more supportive than boys (Furman \& Buhrmester, 1992). Martin et al. (1997) stated that female siblings are more satisfied and reported using less verbal aggression than male dyads or mixed sex dyads .

Accordingly, this study was designed to test the following:

H2: Male siblings will score higher in verbal aggressiveness than female siblings.

Since there may be some differences between one's own perception of aggressive behavior and that reported by a sibling, it was appropriate to test this through both selfreport and other-report techniques. Hence,

H2a: Males' self-reports of verbal aggression will be higher than females' self-reports. 
H2b: Siblings will report that their male siblings are more verbally aggressive than their female siblings. 


\section{Chapter 2}

METHODS

\section{$\underline{\text { Participants }}$}

This study consisted of 338 participants. There were 169 undergraduate students enrolled in mass lecture communication courses at West Virginia University. 151 of the participants were males (45.8\%) and 179 were females (54.2\%). The students were given two options for the study. First, students who had a sibling could themselves participate in the study. Second, those people without siblings were asked to find a pair of siblings and administer the questionnaire to them. Each participant was required to turn in two completed questionnaires (older and younger brother and/or sister responses). After the students returned the questionnaires they were given extra credit in the course.

\section{Instrument}

To measure verbal aggression participants were asked to complete the sibling verbal aggressiveness scale (Teven, Martin, \& Neupauer, 1998). The participants were given two identical surveys. The first survey asked them to focus on one sibling relationship and complete the sibling verbal aggressiveness scale. They needed to report their verbal 
aggressiveness and perceived verbal aggression of their sibling. The second survey was given to their sibling to complete and they were asked to do the same thing.

\section{$\underline{\text { Procedures }}$}

This investigation used a fourteen-item behavioral report of sibling verbal aggressiveness created by Teven, Martin, and Neupauer (1998). The scale consisted of responses from 1 = "never true" to 7 = "always true". There were four of the same surveys distributed in this investigation. The first survey looked at the subject's own verbal aggression, survey two looked at the subjects perceived verbal aggression of their sibling, three was the sibling's own verbal aggression, and survey four looked at the siblings perceived verbal aggression of their sibling. A copy of the questionnaire can be found in Appendix A. In this investigation a coefficient alpha of $.90 \quad(\underline{M}=41.30$, $\underline{S D}=14.49)$ was reported for the first instrument as completed by the participants. Survey two returned a coefficient alpha of $.91(\underline{M}=40.25, \underline{S D}=14.80)$. For the sibling, a coefficient alpha of $.90(\underline{\mathrm{M}}=38.27, \underline{\mathrm{SD}}=13.93)$ was obtained in survey three. Survey four had an coefficient alpha of $.91(\underline{\mathrm{M}}=37.98, \underline{\mathrm{SD}}=14.49)$. 


\section{Chapter 3}

RESULTS

Research Question One asked whether self-reports of verbal aggression were consistent with sibling reports. This was best answered using simple correlational analysis. The correlational coefficients were .62 and .58, considered moderately high.

Hypothesis One stated that same sex sibling pairs will display more verbal aggression than mixed sex siblings pairs. This first hypothesis was tested using a two-way ANOVA. This hypothesis was partially supported $[F(1,328)$, 2.99, $\mathrm{p}<.03, \mathrm{R} 2=.03]$. Male sibling pairs were found to be more verbally aggressive than all other combinations. See Table 1 .

Table 1

\begin{tabular}{lllll}
\hline Gender & SGender & N & Mean & SD \\
Male & Male & 78 & $43.68 \mathrm{abc}$ & 14.94 \\
Male & Female & 73 & $38.51 \mathrm{a}$ & 15.39 \\
Female & Male & 77 & $38.29 \mathrm{~b}$ & 12.99 \\
Female & Female & 102 & $38.25 \mathrm{c}$ & 12.11 \\
\hline
\end{tabular}

* Means with the same subscript are significantly different $(\mathrm{p}<.05)$. 
Hypothesis Two stated that male siblings will score higher in verbal aggressiveness than female siblings. This hypothesis was tested using t-tests. This hypothesis was partially supported. H2a stated that males self-reports of verbal aggression will be higher than females (Males $\underline{M}=$ $41.18, \underline{\mathrm{SD}}=15.33 ;$ Females $\underline{\mathrm{M}}=38.27, \underline{\mathrm{SD}}=12.46)$. This hypothesis was not supported $[F(1,328), 3.62, p>.05$, $\mathrm{R} 2=.01]$. On $\mathrm{H} 2 \mathrm{~b}$, subjects reported that their male siblings were more verbally aggressive towards them than their female siblings were $[F(1,328), 4.58, \mathrm{p}<.03, \mathrm{R} 2=$ .013]. The results indicated that males $(\underline{\mathrm{M}}=40.75, \underline{\mathrm{SD}}=$ 15.22) are reported by their siblings to be more verbally aggressive than females $(\underline{M}=37.34, \underline{S D}=13.73)$. 


\section{Chapter 4 \\ DISCUSSION}

This study was designed to investigate whether the sex of the sibling influences verbal aggression. The results from this study provide little support in regards to siblings and verbal aggression.

Research Question One examined whether or not selfreports of verbal aggression were consistent when compared to sibling reports. Subjects reported the same as their siblings reported in regards to verbal aggression. Self reports and other reports are at least moderately correlated; therefore, the choice of method may not be critical. The correlation between self verbal aggression and sibling verbal aggression suggests that there may be some reciprocity taking place.

Hypothesis One examined whether same sex sibling pairs would display more verbal aggression than mixed sex siblings. One might expect that same sex siblings would be more verbally aggressive than opposite sex siblings; however, this was only proven to be partially supported. Male same sex sibling dyads reported being the most verbally aggressive; whereas, female same sex dyads were not as verbally aggressive. 
Hypothesis Two examined the relationship between sibling gender and verbal aggression. H2a found that males self reports of verbal aggression tended not to be higher than females. When males were filling out the questionnaire, they did not report being more verbally aggressive. H2b claimed that siblings would report that their male siblings are more verbally aggressive than their female siblings. This was supported, indicating that brothers are more verbally aggressive than their sisters.

\section{Future Directions}

This study allows for several implications for future research in the area of sibling verbal aggression and communication. One of the areas that needs to be further examined is birth order. Limited research has been done in this area and its impact on the sibling relationship and verbal aggression. Research has found that family communication patterns are systematically and dynamically interwoven (Stafford \& Dainton, 1994). Collins (1990) stated that as children grow older and societal pressures increase, parents must set up new rules, and the communication patterns are renegotiated between the parents, the parents and children, and between the children themselves. Therefore, it has been found that verbally 
aggressive messages are still present within the entire family system.

Another area that could be examined in this study is age. It would be interesting to look at the number of years between the siblings, but also the age of the two people filling out the survey. It would be interesting to see if older siblings are less verbally aggressive than younger siblings. It would also be interesting to look at age differences and if people become less verbally aggressive as they get older. Sibling relationships often become more important later in life; therefore, they often spend time talking about their past family experiences (Bedford, 1989b; Bedford \& Gold, 1989; Cicirelli, 1985; Goetting, 1986; Ross \& Milgram, 1982). As siblings get older they often need each other during family crises, such as divorce or death (Ambrose, Harper, \& Pemberton, 1983). Another area for future research is comparing gender issues in several different relationships. For instance, friendships, relationships, and sibling relationships. Could verbal aggression be a sibling issue or could it be a gender issue? This study does not address this issue. Another future direction, is looking at what causes siblings to be verbally aggressive. Do siblings do this intentionally and what long term affects does this causes? 


\section{Limitations}

There are several limitations to this study. First, siblings may have been influenced due to social desirability bias. The participant was able to call their sibling on the telephone and record their answers. However, some may have felt that they needed to lie in order to prevent any problems between them and their sibling. The participants may also felt that they needed to make it sound as though they have a good relationship with their sibling. No one wants people to think that the have an unstable relationship or family problems. Participants may have also not have gone with their first instinct and put too much thought in to the question.

Therefore, it is possible that they made their relationship seem more stable than it actually was and affected the results of the study.

This study had to be conducted by participants using self-reports of verbal aggression. Therefore, the results of this study may not be completely accurate. In order to be more accurate, I could have asked the participants to focus on a certain time period when filling out the surveys .

Age of the siblings may also be another limitation. This study consisted only of college students. However, 
over time the sibling relationship is likely to change. Depending on the age of the sibling, the sibling relationship is likely to change. Age will affect the amount of contact between siblings and their living arrangements (Cicirelli, 1995; Goetting, 1986). For instance, many freshmen still may view their siblings in a high school manner. They may have fought a lot when they were younger and have not developed a mature relationship with their sibling. Siblings may have responded differently if they were seniors or they had siblings that were significantly older. The would also responded differently if they shared a room together their whole life verses those who were 10 years apart and may not have spend a lot of time together growing up.

Another limitation may be geographic location. Many people value sibling relationships based on where they are from. Some families are closer than others are and this would affect sibling relationships. People from certain places may spend more time with their siblings and family. It would be interesting to conduct this study in different geographic locations and compare the results.

\section{$\underline{\text { Summary }}$}

This study provided further research in the sibling 
relationship in regards to verbal aggression. This study provides insight; however, it also shows the future direction needed in sibling relationships. Although this study had several limitations, there was also significant findings as well. The findings of this study suggests that males and more verbally aggressive than females.

The area of sibling relationships and verbal aggression can be beneficial to communication scholars as well as family scholars. 


\section{REFERENCES}

Alberts, J. K., Kellar-Guenther, Y., \& Corman, S. R. (1996). That's not funny: Understanding recipients' responses to teasing. Western Journal of Communication, $\underline{96}, 337-357$.

Ambrose, P., Harper, J., \& Pemberton, R. (1983). Surviving divorce: Men beyond marriage. London: Harvester.

Bank, S. P., and Kahn, M. D. (1982). The Sibling Bond, New York.

Beatty, M. J., \& Dobos, J. A. (1992a). Adult sons' satisfaction with their relationships with fathers and person-group communication apprehension. Communication $\underline{\text { Quarterly }}, \underline{40}, 162-176$.

Beatty, M. J., Burant, P. A., Dobos, J.A., \& Rudd, J. E. (1996). Trait verbal aggressiveness and the appropriateness and effectiveness of fathers' interaction plans. Communication Quarterly, $\underline{44}, 1-15$.

Beatty, M. J., Zelley, J. R., Dobos, J. A., \& Rudd, J. E. (1994). Fathers' trait verbal aggressiveness and argumentativeness as predictors of adult sons' perceptions of fathers' sarcasm, criticism, and verbal aggressiveness. Communication Quarterly, $\underline{42}, 407-415$. 
Beatty, M. J., \& McCroskey, J. C. (1997, May). It's in our nature: Verbal aggressiveness as temperamental expression. Paper presented at the Annual Meeting of the Interpersonal Communication Association, Montreal.

Bedford, V. H. (1989b). Understanding the value of siblings in old age. American Behavioral Scientist, 33 , $33-44$

Bedford, V. H., \& Gold, D. T. (1989). Siblings in later life: A neglected family relationship. American Behavioral Scientist, 33, 3-126.

Berschied, E. (1986). Emotional experience in close relationships: Some implications for child development. In Hartup, W. W., and Rubin, Z. (Eds.), Relationships and Development. Erlbaum, Hillsdale, NJ.

Bryant, N. (1982). Sibling relationships in middle childhood. In Lamb, M. E., and Sutton-Smith, B. (eds.), Sibling relationships: Their nature and significance across the lifespan. Erlbaum, Hillsdale, NJ.

Buhrmester, D. (1992). The development courses of sibling and peer relationships. In F. Boer \& J. Dunn (Eds.) Children's sibling relationships: Developmental and clinical issues (pp. 19-40). Hillsdale, NJ: Lawrence Erlbaum. 
Buhrmester, D., and Furman, W. (1990). Perceptions of sibling relationships during middle childhood and adolescence. Child Development 61: 1387-1398.

Cahn, D. D. (1996). Family violence from a communication perspective. In D. D. Cahn \& S. A. Lloyd (Eds.), Family violence from a communication perspective (pp. 1-19). Thousand Oaks, CA: Sage.

Cicirelli, V. G. (1985). Sibling relationships throughout the life cycle. In L. L. Abate (Ed.), The handbook of family psychology and therapy (pp. 177-214). Homewood, IL: The Dorsey Press.

Cicirelli, V. G. (1995). Sibling relationships across the life span. New York: Plenum Press. Cicirelli, V. G., \& Nussbaum, J. F. (1989). Relationships with siblings in later life. In J. F. Nussbaum (Ed.), Life-span communication: Normative processes (pp. 283-300). Hillsdale, NJ: Erlbaum. Collins, W. A. (1990). Parent-child relationships in the transition to adolescence: Continuity and change in interaction, affect, and cognition. In R. Montemayor, G. R. Adams, \& T. P. Gullotta (Eds.), From childhood to adolescence: A transitional period (pp. 85-106). Newbury Park, CA Sage. 
Collins, W. A., \& Repinski, D. J. (1994).

Relationships during adolescence: Continuity and change in interpersonal perspective. In R. Montemayor, G. Adams, \& T. P. Gullotta (Eds.) Personal relationships during adolescence (pp. 7-36). Thousand Oaks, CA: Sage.

Dunn, J. (1983). Sibling relationships in early childhood. Child Development, 54, 787-811.

Dunn, J. (1985). Sisters and brothers. Harvard University Press, Cambridge, MA.

Dunn, J. (1988). The beginnings of social understanding. Harvard University Press, Cambridge, MA.

Dunn, J., \& Kendrick, C. (1982). Siblings: Love, envy, and understanding. Grant McIntyre, London.

Dunn, J. (1993). Young children's close relationships: Beyond attachment. Newbury Park, CA: Sage.

Dunn, J., \& Stocker, C. (1989). The significance of differences in siblings' experiences with the family. In K. Kreppner \& R. M. Lerner (Eds.), Family systems and Iife-span developmental Issues and perspectives (pp. 289302). Hillsdale, NJ: Lawrence Erlbaum Associates. Faber, A., and Mazlish, E. (1987). Siblings without rivalry. Avon, New York.

Floyd, K. (1995). Gender and closeness among friends and siblings. Journal of Psychology, 129, 193-202. 
Floyd, K. (1996). Communicating closeness among siblings: An application of the gendered closeness perspective. Communication Research Reports, 13, 27-34.

Floyd, K. (1997). Brotherly love II: A developmental perspective of liking, love, and closeness in the fraternal dyad. Journal of Family Psychology, 11, 196-209.

Fitzpatrick, M. A., \& Badzinski, D. M. (1994). All in the family: Interpersonal communication in kin relationships. In M. L. Knapp \& G. R. Miller (Eds.), $\underline{\text { Handbook of Interpersonal Communication }}$ ( $2^{\text {nd }}$ ed., pp. 726771). Newbury Park, CA: Sage.

Freud, S. (1955). The interpretation of dreams. Basic, New York.

Furman, W., and Buhrmester, D. (1992). Age and sex differences in perceptions of networks of personal relationships. Child Development 63: 103-115.

Goetting, A (1986). The developmental tasks of siblingship over the lifestyle. Journal of Marriage and the Family, $\underline{48}, 703-714$.

Goode, E. E. (1994, January 10). The secret world of siblings: Emotional ambivalence often marks the most enduring relationship later in life. U.S. News \& World Report, 116 (1), 44-50. 
Goodwin, M. P., and Roscoe, B. (1990). Sibling violence and agonistic interactions among middle adolescents. Adolescence 15: 451-467.

Gudykunst, W., Yoon, Y. C., \& Nishida, T. (1986). The developmental tasks of siblingship over the life cycle. Journal of Marriage and the Family, $\underline{48}, 703-714$.

Hay, D. F. (1984). Social conflict in early childhood. In Whitehurst, G. (Ed.), Annals of Child Development (Vol. $1)$.

Holmes, J. G., \& Rempel, J. K. (1980). Trust in close relationships. In C. Hendrick (Ed.) Close relationships (pp. 187-220). Newbury Park, CA: Sage.

Infante, D. A. (1987). Aggressiveness. In J. C. McCroskey \& J. A. Daly (Eds.) Personality and interpersonal communication (pp. 157-192). Newbury Park, CA: Sage.

Infante, D. A., Myers, S. A., \& Buerkel, R. A. (1994). Argument and verbal aggression in constructive and destructive family and organizational disagreements. Western Journal of Communication, 58, 73-84.

Infante, D. A. (1995). Teaching students to understand and control verbal aggression. Communication Education, $\underline{44}, 51-63$. 
Infante, D. A., Bruning, S. D., \& Martin, M. M. (Nov., 1994). The verbally aggressive individual: Experiences with verbal aggression and reasons for use. Paper presented at the meeting of the Speech Communication Association, New Orleans.

$$
\text { Infante, D. A., \& Rancer, A. S. (1996). }
$$

Argumentativeness and verbal aggressiveness: A review of recent theory and research. Communication Yearbook, 19 , $319-351$.

Infante, D. A., \& Wigley, C. J. III. (1986). Verbal aggressiveness: An interpersonal model and measure. Communication Monographs, 53, 61-69.

Kidwell, J. S. (1981). Number of siblings, sibling spacing, sex, and birth order: Their effects on perceived parent-adolescent relationships. Journal of Youth Adolescence 21: 315-333.

Kinney, T. A. (1994). An inductive derived typology of verbal aggression and its association to distress.

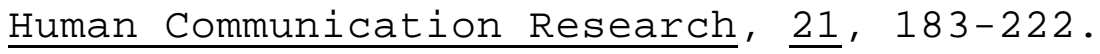
Klagsbrun, F. (1992). Mixed feelings: Love, hate, rivalry, and reconciliation among brothers and sisters. New York, Bantam Books. 
Lamb, M. E., and Sutton-Smith, B. (1982). Sibling relationships: Their nature and significance across the lifespan. Erlbaum, Hillsdale, NJ.

Lee, T. R., Mancini, J. A., \& Maxwell, J. W. (1990). Sibling relationships in adulthood: Contact patterns and motivations. Journal of Marriage and the Family, $\underline{52}$, 56$58+$.

Martin, M. M., \& Anderson, C. M. (1995). Roommate similarity: Are roommates who are more similar in their communication traits more satisfied. Communication $\underline{\text { Research Reports, }} \underline{12}, 46-52$.

Martin, M. M., Anderson, C. M., \& Horvath, C. (1996). Feelings about verbal aggressivness: Justifications for sending and hurt from receiving verbally aggressive messgaes. Communication Research Reports, 13, 19-26.

Martin, M. M., Anderson, C. M., Burant, P. A., \& Weber, K. (1997). Verbal aggression in sibling relationships. Communication Quarterly, $\underline{45}, 304-317$.

Montemayor, R., and Hanson, E. (1985). Anaturalistic view of conflict between adolescents and their parents and siblings. Journal of Early Adolescence 5: 23-30.

Newman, J. (1991). College students' relationships with siblings. Journal of Youth Adolescence 20: 629-644. 
Nicotera, A. M., \& Rancer, A. S. (1994). The influence of sex on self-perceptions and social stereotyping of aggressive communication predispositions. Western Journal of Communication, 58, 283-307.

Noller, P., \& Fitzpatrick, M. A. (1993).

Communication in family relationships. Englewood Cliffs, NJ: Prentice Hall.

Parke, R. D. (1992). Epilogue: Remaining issues and future trends in the study of family-peer relationships. In R. Parke \& G. Ladd (eds.), Family-peer relationships: Modes of linkage (pp. 425-435). Hillsdale, NJ: Lawrence Erlbaum .

Richardson, R. A., Abramowitz, R. H., Asp, C. E., and Petersen, A. C. (1986). Parent-child relationships in early adolescence: Effects of family structure. Journal Marriage Family 48: 805-811.

Rogers, J. L., and Rowe, D. C. (1988). Influence on siblings on adolescent sexual behavior. Developmental Psychology 24: 722-728.

Roscoe, B., Goodwin, M. P, and Kennedy, D. (1987). Sibling violence and agonistic interactions experienced by early adolescents. Journal of Family Violence 2: 121-137. 
Ross, H. G. \& Milgram, J. I. (1982). Important variables in adult sibling relationships: A qualitative study. In M. E. Lamb \& B. Sutton-Smith (Eds.), Sibling relationships: Their nature and significance across the lifespan (pp. 225-249). Hillsdale, NJ: Erlbaum.

Shantz, C. U. (1987). Conflicts between children. Child Development 58: 283-305.

Shantz, C. U., and Hobart, C. J. (1989). Social conflict and development: Peers and siblings. In Berndt, $T$. J. and Ladd, G. W. (eds.), Peer Relationships in Child Development. Wiley, New York.

Stafford, L., \& Bayer, C. L. (1993). Interpersonal communication between parents and children. Newbury Park, CA: Sage.

Stafford, L., \& Dainton, M. (1994). The dark side of "normal" family interaction. In W.R. Cupach \& B.H. Spitzberg (Eds.), The dark side of interpersonal communication (pp. 259-280). Hillsdale, NJ: Lawrence Erlbaum.

Stormshak, E.A., Bellanti, C.J., \& Bierman, K.L. (1996). The quality of sibling relationships and the development of social competence and behavioral control in aggressive children. Developmental Psychology, $\underline{32}, 79-89$. 
Teven, J. J., Martin, M. M., \& Neupauer, N. C. (1998). Sibling relationships: Verbally aggressive messages and their effect on relational satisfaction, Communication Reports, $11,179-186$.

Vandell, D. L., Minnett, A. M., \& Santrock, J. W. (1987). Age differences in sibling relationships during middle childhood. Journal of Applied Developmental Psychology 8: 247-257.

Vangelisti, A. L. (1993). Communicaiton in the family: The influence of time, relational prototypes, and irrationality. Communication Monographs, 60, 42-54. 
Appendix A

Instructions: Please indicate how frequently you do the following things to your sibling.

$\begin{array}{ccccccc}\text { Never } & \text { Rarely } & \text { Seldom } & \text { Sometimes } & \text { Often } & \text { Mostly } & \text { Always } \\ \text { True } & \text { True } & \text { True } & \text { True } & \text { True } & \text { True } & \begin{array}{c}\text { True } \\ \mathbf{1}\end{array} \\ \mathbf{2} & \mathbf{3} & \mathbf{4} & \mathbf{5} & \mathbf{6} & \mathbf{7}\end{array}$

1. Attack their intelligence.

2. Make fun of their dating or lack of relationships.

3. Make fun of their friendships.

4. Call them uncomplimentary nicknames.

5. Make fun of their physical appearance.

6. Threaten to get them in trouble.

7. Threaten to hurt them physically.

8. Make fun of their friends in front of them.

9. Complain about something they've done.

10. Attack their self-esteem.

11. Threaten to abuse or destroy a possession of theirs.

12. Make fun of them in front of their friends.

13. Tease them.

14. Swear at them. 
Instructions: Please indicate how frequently your sibling does the following to you.

$\begin{array}{ccccccc}\text { Never } & \text { Rarely } & \text { Seldom } & \text { Sometimes } & \text { Often } & \text { Mostly } & \text { Always } \\ \text { True } & \text { True } & \text { True } & \text { True } & \text { True } & \text { True } & \text { True } \\ \mathbf{1} & \mathbf{2} & \mathbf{3} & \mathbf{4} & \mathbf{5} & \mathbf{6} & \mathbf{7}\end{array}$

1. Attack your intelligence.

2. Make fun of your dating or lack of relationships.

3. Make fun of your friendships.

4. Call you uncomplimentary nicknames.

5. Make fun of your physical appearance.

6. Threaten to get you in trouble.

7. Threaten to hurt you physically.

8. Make fun of your friends in front of you.

9. Complain about something you've done.

10. Attack your self-esteem.

11. Threaten to abuse or destroy a possession of yours.

12. Make fun of you in front of your friends.

13. Tease you.

14. Swear at you.

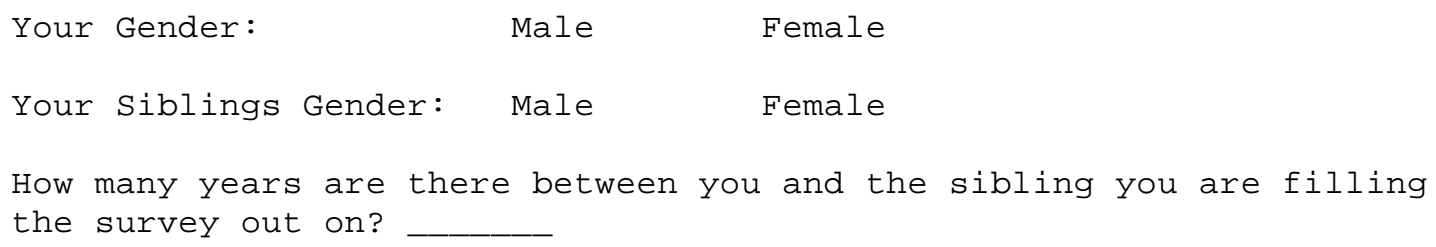

